\section{Helhetlig om omsorgssvikt}

Killén K.

Sveket I

Barn i risiko- og omsorgssviktsituasjoner

462 s. Oslo: Kommuneforlaget, 2009

Pris NOK 498

ISBN 978-82-446-1293-7

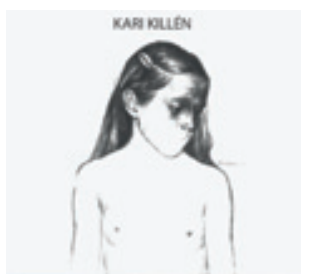

Forfatter dr.philos.

Kari Killén deler

rikelig av sin store

kunnskap om omsorgssvikt hos

barn. Hun har bred

klinisk erfaring,

er en anerkjent

forsker og har

gjennom mange

år vært en aktiv

og aktet deltaker

i det internasjonale fagmiljøet.

Sveket I er fjerde reviderte utgave av første del av Sveket (1) som kom ut i 1991.

Sveket I omhandler forståelsesgrunnlaget for omsorgssvikt og dets konsekvenser. Sveket II vil komme ut senere i 2010 og omhandle (be)handling. Boken ble delt da den ellers ville blitt for stor, og med sine 462 sider er Sveket I allerede omfangsrik. Det er få illustrasjoner, slik at den i tillegg er ordrik. Mangel på illustrasjoner kompenseres noe av at det $\mathrm{i}$ teksten er lagt inn små kliniske eksempler som bidrar til å understreke poengene og gjøre stoffet mer levende. Som hovedinntrykk er dette vellykket, selv om eksemplene enkelte ganger virker konstruerte.

Målgruppen er alle som møter omsorgssvikt i sitt arbeid, samt politikere og frivillige hjelpere. Forfatteren går så grundig gjennom temaene at det ikke er behov for mye forkunnskap. Dette gjør boken lang, og gjentakelser forekommer mellom kapitlene. Imidlertid har forfatteren vært flink til å få inn nytt stoff, og lesere som er godt inne i temaet, vil også bli engasjert.

Innholdsmessig er teksten delt i fire. Første del er godt oppdatert og tar for seg bakgrunnsinformasjon, slik som forekomst og definisjoner. Andre del omhandler hvordan vi kan forstå omsorgssvikt, og forfatteren introduser hva hun beskriver som en helhetlig modell for forståelse og analyse av omsorgssvikt. Hvert hovedelement i modellen blir gjort rede for i de følgende kapitlene. Dette er bokens hoveddel og den som faglig gir mest. I tredje del beskrives kontaktetablering og undersøkelse der det er mistanke om omsorgssvikt. Denne delen er mest relevant for barnevernsarbeidere, men gir gode råd også for de med mer perifere roller i slike prosesser. I siste del diskuteres samarbeid på en noe selvfølgelig måte, og mange lesere vil nok stoppe her.

Med sin helhetlige profil, og med forfatterens kunnskap samlet gjennom mange tiår i front av feltet, er dette en viktig utgivelse. Den vil gi nyttig og ny kunnskap til de fleste som arbeider med barn, samtidig som den er en påminnelse om hvor viktig det er å avdekke omsorgssvikt og handle der barn er i risikosonen. Boken vil med sitt barneperspektiv også gi verdifull innsikt for de som arbeider med foreldre som er i risikosonen for å utsette barna sine for omsorgssvikt.

\section{Mia Cathrine Myhre}

Nasjonalt kunnskapssenter om vold og traumatisk stress

Oslo

\section{Litteratur Oslo: Kommuneforlaget,1991. \\ Menneskets biologi i detalj og helhet}

1. Kari Killén. Sveket. Omsorgssvikt er alles ansvar.

Søvik 0 .

Livet som lovmessighet og sjansespill

231 s, ill. Trondheim: Tapir akademisk forlag,

2009. Pris NOK 285

ISBN 978-82-519-2521-1

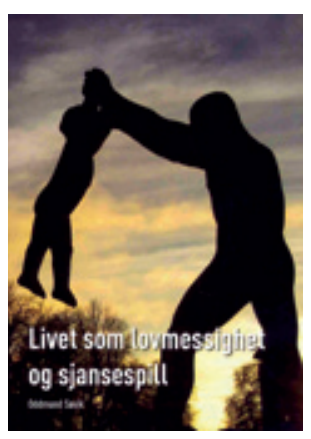

«Utgangspunktet for denne boka har vært, og er, et dyptfølt behov for å forstå livsprosessene, både som konkrete, fysiske foreteelser og i en videre tankemessig (filosofisk) sammenheng.» La meg si det med en gang: Jeg synes forfatteren har lyktes imponerende godt med å formidle så vel grunnleggende kunnskap om livsprosessene som biologien sett $i$ et større, humanistisk perspektiv. Så kan da forfatteren sies å være godt «utdannet» for å greie en slik oppgave:
Et langt og aktivt liv som barnelege $o g$ grunnforsker - kombinert med (åpenbart) stadig undring og refleksjon - har sannsynligvis gitt en daglig erfaring om at en god lege må beherske både detaljene og helheten.

Det er et ambisiøst prosjekt å skrive om de mest sentrale tema innen menneskelig eksistens på rundt 200 sider. Faren for overfladiskhet, selvfølgeligheter og overforenklinger er utvilsomt stor. Søvik greier imidlertid å skrive lettfattelig, nyansert og presist, uten å ty til snarveier. Jeg blir minnet om et utsagn tillagt Thomas Aquinas: «Bare den som bruker sin fornuft, vet når fornuften ikke lenger strekker til.» Det passer godt her: Der naturvitenskapen gir klare svar, formidler forfatteren dem, men der hvor de ennå mangler, eller hvor naturvitenskapen ikke kan gi svar, greier han å formidle ulike syn og hva usikkerheten ligger i. Særlig mot slutten bruker han relativt mye plass på å diskutere grensene mellom naturvitenskap (særlig biologi), filosofi og religion. Han greier å drøfte de vanskeligste, eksistensielle spørsmålene som mennesker alltid har tumlet med, uten å bli overfladisk eller distansert teoretisk.

Boken er delt inn i 12 kapitler. Kapittel 1 drøfter skillet mellom levende og død materie, mens kapittel 2 går direkte på spørsmålet om tilfeldigheter og nødvendighet i biologien. Er det for eksempel grunnlag for å si at biologiske prosesser er målrettede? Er det holdbart å bruke teleologiske forklaringer på biologiske fenomener? Kapittel 3 dreier seg om livets opprinnelse, mens kapitlene 4, 5 og 6 drøfter utviklingen av livet på jorden, reproduksjonen og embryogenesen. Her gis en lettfattelig, men likevel presis og kritisk fremstilling av grunnlaget for evolusjonen og menneskets plass i naturen. Samtidig drøftes andre forklaringsmodeller på menneskets uvikling, som kreasjonisme og «intelligent design». Forfatteren fører leseren fra de grunnleggende biologiske forholdene til - blant annet - drøfting av grensen mellom det naturlige og det menneskeskapte og etiske overveielser rundt eugenikk og preimplantasjonsdiagnostikk. Kapittel 7 omhandler aldring og død - igjen først med formidling av hva aldring er i biologisk forstand, og ulike biologisk baserte teorier. I kapittel 8 formidles først kunnskap om kreftsykdommers biologi med etterfølgende drøfting av kreft som tilfeldighet eller nødvendighet. Kapittel 9 gir først en kort innføring i hjernens 